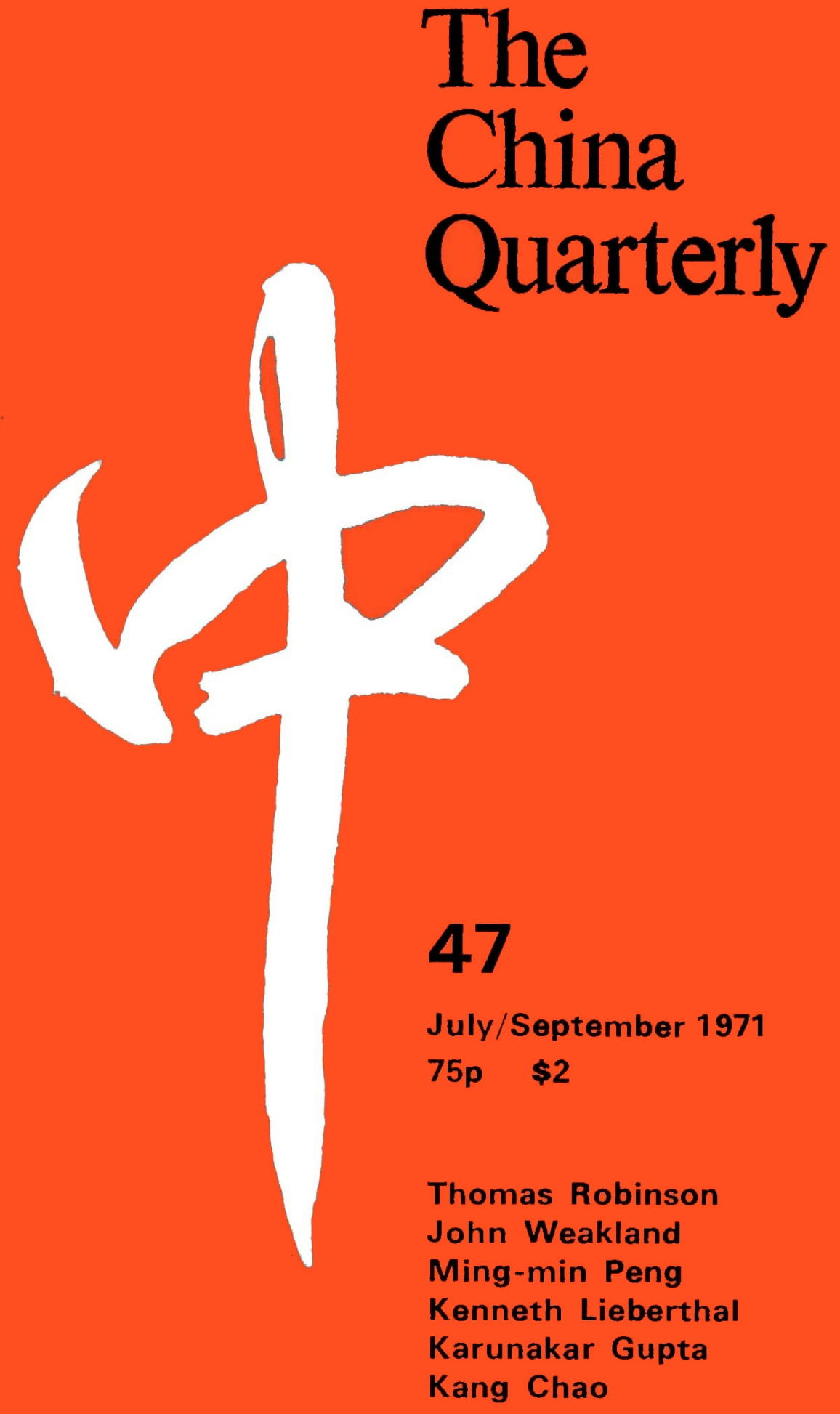




\section{John King Fairbank}

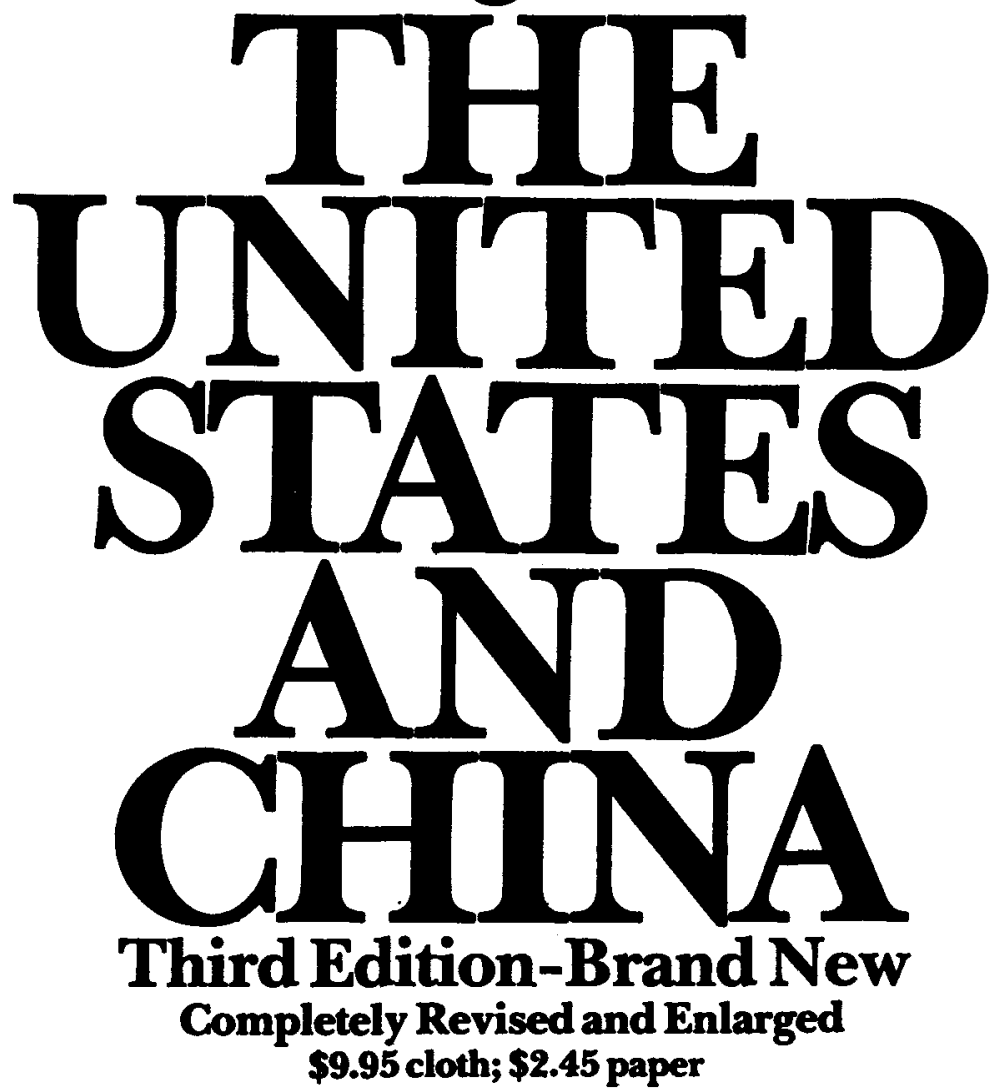

The noted Harvard Sinologist updates his classic work on the United States and China.

"No one has written more clearly or perceptively about China during the past quarter century than Professor Fairbank. ... The extensive new sections on more recent events constitute the clearest, most balanced, and most judicious brief presentation that I have yet seen."

Edwin O. Reischauer

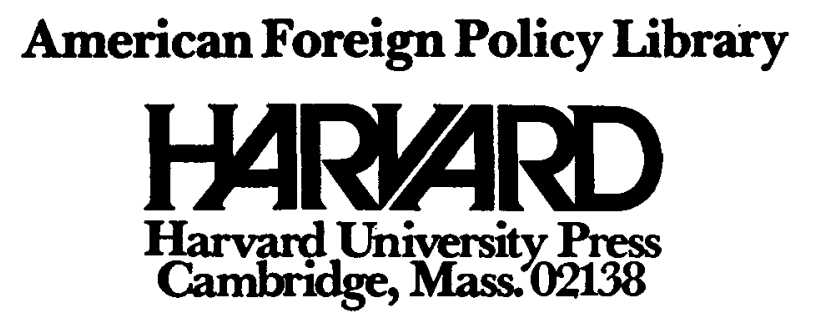




\section{The China Quarterly}

an international journal for the study of China

July/September 1971 number 47

THE WUHAN INCIDENT: LOCAL STRIFE AND PROVINCIAL REBELLION DURING THE CULTURAL REVOLUTION Thomas W. Robinson

CHINESE FILM IMAGES OF

INVASION AND RESISTANCE John H. Weakland

POLITICAL OFFENCES IN TAIWAN:

LAWS AND PROBLEMS Ming-min Peng

MAO VERSUS LIU? POLICY TOWARDS

INDUSTRY AND COMMERCE: 1946-49

Kenneth Lieberthal 494

THE MCMAHON LINE Karunakar Gupta

SINO-SOVIET EXCHANGE RATES Kang Chao

Review Article:

THE IMPACT OF CHINESE SECRET SOCIETIES IN MALAYA: AN HISTORICAL STUDY The History of Secret Societies in Malaya. By Wilfred Blythe, Wang Gungwu

Comment:

On Missing Photographs. Donald Klein

Book Reviews:

Foreign Relations of the United States: 1945, Vol. VII: The Far East, China. Washington: Government Printing Office. Akira Iriye

Collected Works of Liu Shao-ch'i: Vols. I, II, III. Hong Kong, Union Research Institute. Stuart R. Schram

Agricultural Development in China 1368-1968. By Dwight H. Perkins. James T. Myers 
CONTENTS-continued

Russia, China, and the West. A Contemporary Chronicle, 1953-1966. By Isaac Deutscher. Edited by Frank Halliday. John Gittings

Learning to be Chinese: The Political Socialization of Children in Taiwan. By Richard W. Wilson. Edwin Winckler

Mao Tse-tung sheng-p'ing tzu-liao chien-pien: 1893-1969 (Mao Tse-tung: a Collection of Raw Materials Regarding His Life, 1893-1969). Compiled by Huang Yü-ch'uan. Stuart R. Schram

While China Faced West: American Reformers in Nationalist China, 19281937. By James C. Thomson, Jr. Charles Hayford

Vidnye Sovetskie Kommunisty-Unchastniki Kitaiskoi Revolutsii (The Outstanding Soviet Communists, Participants in the Chinese Revolution). Moscow: "Nauka" Publishing House. Lydia Holvbnychy

Dynamics of China's Foreign Relations. Edited by Jerome Alan Cohen. Kim Woodard

The Foreign Relations of China. By Robert C. North. Michael B. Yahuda

The Government and Politics of Communist China. By Derek J. Waller. J. L. Nichols

The Prediction of Communist Economic Performance. Edited by P. J. D. Wiles. Christopher Howe

China: The Revolution Continued. By Jan Myrdal and Gun Kessle. Andrew Watson

Book Notes

Quarterly Chronicle and Documentation (April-June 1971)

Contributors 